Original Research Article

\title{
Protective effect of Phyllanthus fraternus against cyclophosphamide- induced nephrotoxicity in rats
}

\author{
Rakesh Singh Moirangthem ${ }^{1 *}$, Ngangom Gunindro ${ }^{1}$, Dipdeba Singh Takhellambam², \\ Sucheta Devi Khuraijam ${ }^{2}$, N. Meena ${ }^{1}$, S. Rita ${ }^{1}$
}

\author{
${ }^{1}$ Department of Pharmacology, \\ Regional Institute of Medical \\ Sciences, Imphal, Manipur, \\ India \\ ${ }^{2}$ Department of Pathology, \\ Regional Institute of Medical \\ Sciences, Imphal, Manipur, \\ India
}

Received: 07 February 2017

Accepted: 06 March 2017

\section{*Correspondence to:}

Dr. Rakesh Singh Moirangthem, Email: rakesmoir@gmail.com

Copyright: (c) the author(s), publisher and licensee Medip Academy. This is an openaccess article distributed under the terms of the Creative Commons Attribution NonCommercial License, which permits unrestricted noncommercial use, distribution, and reproduction in any medium, provided the original work is properly cited.

\begin{abstract}
Background: Cyclophosphamide is commonly used against malignancies, such as leukemia and solid organ cancers. It can induce nephrotoxicity in cancer patients thereby complicating the initiation of chemotherapy. The study is to evaluate the effect of Phyllanthus fraternus against cyclophosphamide induced nephrotoxicity in albino rats.

Methods: In this study, a total of 20 albino rats were divided into four groups of five each. Group I (normal control) received i.p. injection of normal saline. While, group II, III and IV received single dose $(200 \mathrm{mg} / \mathrm{kg} \mathrm{b} / \mathrm{w})$ of cyclophosphamide i.p. on day 1. Group III and IV received $200 \mathrm{mg} / \mathrm{kg}$ and 400 $\mathrm{mg} / \mathrm{kg}$ of aqueous extract of Phyllanthus fraternus respectively p.o. daily for 10 days. All the groups were fed with standard diet and water ad libitum. Serum levels of creatinine, urea and albumin were estimated. Histopathology of renal tissues was compared among the groups.

Results: The renal parameters significantly improved in groups III and IV after 10 days of treatment with the extract. The histopathology study also supported the finding.

Conclusions: The aqueous extract of Phyllanthus fraternus possesses protective effect against cyclophosphamide induced nephrotoxicity.
\end{abstract}

Keywords: Cyclophosphamide, Nephrotoxicity, Nephroprotective, Phyllanthus fraternus

\section{INTRODUCTION}

Nephrotoxicity is one of the major kidney problems caused by drug or toxin. ${ }^{1}$ Drugs, radiocontrast agents and heavy metals are well known to be nephrotoxic. ${ }^{2}$ Cyclophosphamide (CP) is an immunosuppressive and cytotoxic drug used in various clinical scenarios such as tissue transplantation, autoimmune disorders and neoplasia. It is an alkylating agent belonging to the nitrogen mustard subclass of anticancer drugs. In human, serum the half-life of cyclophosphamide is about 6.5 hours. ${ }^{3}$ Tubular reabsorption of cyclophosphamide is very high. So, a very small fraction of it excreted through the kidneys. ${ }^{4}$ Active metabolites of cyclophosphamide i.e., acrolein and phosphoramide mustard generated in the body act as free radicals that cause damage to renal microstructures. ${ }^{5}$

Herbal drugs are readily available, low cost, and with less side effects. Indian medicinal plants also provide a rich source for antioxidants that are known to prevent or delay different diseased states. ${ }^{6}$ The medicinal plants also contain other beneficial compounds or ingredients which can be used as food. ${ }^{7}$ They are the potential source of therapeutics aids and played a significant role in the health care system all over the world. They not only provide relief to diseased conditions but also help in maintaining health in day to day life. Studies done on nephroprotective properties of various medicinal plants like Allium sativum, Zingiber officinale, Curcuma longa, ${ }^{1}$ 
Butea monosperma, Tinospora cordifolia etc, used drug induced animal models of acute nephrotoxicity. ${ }^{8-12}$

Phyllanthus fraternus is a medicinal herb growing widely in most tropical and subtropical countries. The plant belongs to Euphorbiaceae family. ${ }^{13}$ In India, Phyllanthus fraternus is mixed with other Phyllanthus spp., to make a polyherbal preparation called 'Bhumyamlaki', which is widely used against medical problems of the genitourinary tract, anuria and hiccups. ${ }^{14}$ Phytochemical analysis of plant extract reveals presence of alkaloids, tannins, saponin, terpenoid and steroid which are medicinally important bioactive compounds. ${ }^{15,16}$ Aerial part of the plant shows greater antioxidant property by virtue of its higher polyphenolic content. ${ }^{17}$ Aqueous extract of the plant has shown hepatoprotective effect against CP induced oxidative liver injury, which may serve as a promising medicinal herb in the protection against similar oxidative damage to other vital organs. ${ }^{18}$

The study was undertaken to evaluate the protective effect of aqueous extract of Phyllanthus fraternus leaves (AEPF) against cyclophosphamide induced nephrotoxicity in rats.

\section{METHODS}

The study was conducted in the Departments of Pharmacology and Pathology, RIMS, Imphal, India from November 2014 to July 2016.

\section{Drugs and chemicals}

Cyclophosphamide $\left(\right.$ CYPHOS $\left.^{\mathrm{TM}}\right)$ was purchased from Getwell Pharmaceuticals, Haryana, India. Biochemical estimation and analyzing kits for serum creatinine, urea and albumin were purchased from Avantor Performance Materials India Ltd, Uttarakhand, India. All other chemicals and solvents used were of analytical grade. Standard pellet diets were procured from Amricon Agrovet Private Limited, India.

\section{Plant material}

The fresh plant of $P$. fraternus was collected from the Lamphel area, Imphal, Manipur in the month of August. The plant was identified and authenticated by Dr. P. K. Singh, Professor, Department of Life Sciences, Manipur University, Imphal. A voucher specimen was kept in the University herbarium for reference (Voucher no. 000874).

\section{Preparation of extract}

The plant leaves were washed and shade dried. The leaves were powdered by mixer grinder and stored in an airtight container for future use. Preparation of aqueous extract was done by the method described by Verma SCL and Agrawal SL. ${ }^{19}$ The powdered leaves were extracted with distilled water using soxhlet apparatus. The greenish brown extract obtained was filtered, spread in an evaporating dish and dried on a hot water bath. The dried extract was scraped out, weighed and stored in glazed porcelain jar for use in the experiment. The yield was $13.5 \%$.

\section{Phytochemical studies}

Phytochemical tests using standard techniques confirmed the presence of tannins, alkaloids, flavonoids, terpenoids, steroids and saponins. ${ }^{20,21}$

\section{Acute toxicity testing}

Acute toxicity test was carried out as per the OECD guidelines 423 in female albino rats ( 3 rats per step). ${ }^{22}$ The rats were fasted for overnight with water ad libitum. Then, aqueous extract of Phyllanthus fraternus was administered to the fasted rats at a dose of $300 \mathrm{mg} / \mathrm{kg}$ by feeding tube. Food was withheld for further 3-4 h and observed once in every $30 \mathrm{~min}$ during the first $24 \mathrm{~h}$ and thereafter, daily for a period of 14 days for any mortality. As there was no mortality, the procedure was repeated with higher dose of $2000 \mathrm{mg} / \mathrm{kg}$ and animals were observed for mortality and toxic symptoms. It was observed that the dose of $2000 \mathrm{mg} / \mathrm{kg}$ caused no mortality or toxic symptoms among the tested animals and considered safe. Two doses of $200 \mathrm{mg} / \mathrm{kg}$ (1/10th of the maximum test dose) and $400 \mathrm{mg} / \mathrm{kg}$ of AEPF were used as working doses for the experiment.

\section{Selection of animals}

The young adult Wistar albino rats of either sex weighing 150 to $210 \mathrm{~g}$ age between 3 months and 1 year procured from the Animal House, RIMS, Imphal, India were used for the study. The animals were kept in polypropylene cages in room temperature under $12 \mathrm{~h}$ light:dark cycle for 1 week in the animal room of Department of Pharmacology, RIMS, Imphal for acclimatization. They were fed with standard pellet diet with free access to water.

\section{Inclusion and exclusion criteria}

Baseline serum levels of creatinine, urea and albumin were estimated and normal reference ranges were calculated assuming the values are normally distributed. ${ }^{23}$ The value ranges are of $0.4-1.3 \mathrm{mg} / \mathrm{dl}, 10-42 \mathrm{mg} / \mathrm{dl}$ and 3.5-4.5 g/dl respectively. Animals with higher serum levels of creatinine and urea more than the above ranges and lower serum albumin levels below the given reference range were excluded.

\section{Experimental design}

In the study, doses of 200 and $400 \mathrm{mg} / \mathrm{kg}$ body weight of AEPF were selected as working doses based on acute toxicity data. The animals were divided into 4 groups (I, II, III and IV) of 5 animals each (Table 1). On day 1, the 
group I animals were given $0.5 \mathrm{ml} / 100 \mathrm{~g}$ of normal saline (NS) intraperitoneally (i.p.) as single injection.

Table 1: Allotment of animals to different groups and treatments given.

\begin{tabular}{|lll|}
\hline Groups & $\begin{array}{l}\text { Drugs given as } \\
\text { single dose on } \\
\text { day } 1 \text { (i.p.) }\end{array}$ & $\begin{array}{l}\text { Drugs given as } \\
\text { single daily dose } \\
\text { for } 10 \text { days }(\text { p.o. })\end{array}$ \\
\hline I (Normal) & $\begin{array}{l}0.5 \mathrm{ml} \text { of } 0.9 \% \mathrm{NS} \\
2 \% \text { gum acacia in } \\
\text { DW }(1 \mathrm{ml} / 100 \mathrm{~g})\end{array}$ \\
\hline II (CP) & $\begin{array}{l}\text { Cyclophosphamide } \\
(200 \mathrm{mg} / \mathrm{kg})\end{array}$ & $\begin{array}{l}2 \% \text { gum acacia in } \\
\text { DW }(1 \mathrm{ml} / 100 \mathrm{~g})\end{array}$ \\
\hline III (Test 1) & $\begin{array}{l}\text { Cyclophosphamide } \\
(200 \mathrm{mg} / \mathrm{kg})\end{array}$ & $\begin{array}{l}\text { AEPF suspension } \\
(200 \mathrm{mg} / \mathrm{kg})\end{array}$ \\
\hline IV (Test 2) & $\begin{array}{l}\text { Cyclophosphamide } \\
(200 \mathrm{mg} / \mathrm{kg})\end{array}$ & $\begin{array}{l}\text { AEPF suspension } \\
(400 \mathrm{mg} / \mathrm{kg})\end{array}$ \\
\hline
\end{tabular}

Similarly, groups II, III and IV animals were administered CP $(200 \mathrm{mg} / \mathrm{kg})$ mixed in NS at a volume of $0.5 \mathrm{ml} / 100 \mathrm{~g}$ i.p. Animals in groups I and II were given $2 \%$ gum acacia in distilled water at dose of $1 \mathrm{ml} / 100 \mathrm{~g}$ orally for 10 days. Groups III and IV animals were made to receive 200 and $400 \mathrm{mg} / \mathrm{kg}$ of $\mathrm{AEPF}$ respectively suspended $2 \%$ gum acacia orally daily. AEPF was suspended in $2 \%$ gum acacia in distilled water (DW) in such a way that $1 \mathrm{ml}$ contained the calculated doses. Both control and treated animals were observed for 10 days after the i.p. injection for the general appearance, behaviour and mortality.

\section{Blood collection}

Blood samples were drawn before any treatment was given to the animals to assess the baseline biochemical parameters. The animals were anaesthetized with ether and blood samples were collected by retro-orbital venous sinus puncture. ${ }^{24}$ About $2 \mathrm{ml}$ of blood from each animal were collected in a vacutainer from all groups and allowed to clot. The blood was then centrifuged at speed of $3000 \mathrm{rpm}$ for $10 \mathrm{~min}$. The serum separated was kept in refrigerator at $4^{\circ} \mathrm{C}$. It was used for biochemical estimation of creatinine, urea and albumin. The samples were again taken on day 11 .

\section{Biochemical estimations}

Serum biochemical parameters were assessed using commercially available test kits as per the standard methods described. Serum creatinine, urea and albumin were estimated by using Jaffe's kinetic method, Berthelot method and Bromocresol green end-point reaction. ${ }^{25-27}$

\section{Determination of relative kidney-somatic index (kidney to body weight ratios) $)^{28}$}

Kidney-somatic index $=$

\section{Histopathological preparation and scoring}

A midline abdominothoracic incision was performed under ether anaesthesia. Kidneys were quickly dissected out, washed in ice cold saline, dried on filter paper and weighed immediately. The tissues were fixed in $10 \%$ neutral buffered formalin for 48 hours. Renal tissues were prepared for histopathological examination using standard techniques. ${ }^{29}$

Tissue sections (5 $\mu \mathrm{m}$ thick) of the kidneys were prepared, stained with haematoxylin and eosin (H\&E). The sections were observed under light microscope for histopathological changes. The histological scoring was performed based on the following parameters - tubular degeneration, necrosis, tubular dilatation, hyaline protein casts and interstitial leucocytic infiltration.30 These parameters were assessed and graded in the scale of 0 to 5 ( $0=$ normal histology, $1=$ degeneration only without necrosis, $\quad 2 \leq 25 \%, \quad 3=25-50 \%, \quad 4=51-75 \%, \quad 5 \geq 75 \%$ degeneration with necrosis in 20 high power fields). The histological scores were compared among different treatment groups.

The animal carcasses were buried deep in the ground covered with lime and disinfectants after the experiment. $^{31}$

\section{Statistical analysis}

The results of serum biochemical parameters and histological scoring were analyzed using one way ANOVA followed by Dunnett's t-test using SPSS version 21. P value less than 0.05 was considered significant.

\section{RESULTS}

Administration of $\mathrm{CP}$ to rats significantly decreased $(\mathrm{P}<0.001)$ the body weight and absolute kidney weights. Co-administration of CP with AEPF causes lesser body weight loss and increases the kidney weights significantly $(\mathrm{P}<0.001)$. However, there was no significant difference in kidney-somatic index (KSI) among various groups (Table 2).

The treatment of $\mathrm{CP}$ to rats significantly increased $(\mathrm{P}<0.001)$ the serum levels of creatinine and urea as compared to the control group. Oral administration of AEPF in $C P$ treated rats significantly $(\mathrm{P}<0.01)$ decreases creatinine and urea levels compared with $\mathrm{CP}$ only treated group. Serum albumin level significantly decreased $(\mathrm{P}<0.001)$ in $\mathrm{CP}$ treated rats compared with normal group. But the levels were increased in AEPF treated groups significantly when compared with the CP only treated group (Table 3). The histopathological observations of effect of AEPF extract on CP-intoxicated rats are shown in Figure 1. The microscopic examination of kidneys in the normal control rats revealed normal renal glomeruli surrounded by Bowman's capsule. 
Table 2: Changes in the body weight, weight of kidneys and relative kidney to body weight ratio of normal, $\mathrm{CP}$ and AEPF treated groups of rats.

\begin{tabular}{|llllll|}
\hline Groups & $\begin{array}{l}\text { Initial BW } \\
(\mathrm{g})\end{array}$ & $\begin{array}{l}\text { Final BW } \\
(\mathrm{g})\end{array}$ & $\begin{array}{l}\text { Weight diff. } \\
(\mathrm{g})\end{array}$ & Weight of 2 kidneys $(\mathrm{g})$ & $\begin{array}{l}\text { Kidney somatic Index } \\
\left(\times 10^{-3}\right)\end{array}$ \\
\hline I & $174.60 \pm 21.40$ & $190.80 \pm 19.00$ & $16.20 \pm 4.54$ & $1.27 \pm 0.03$ & $6.70 \pm 0.38$ \\
\hline II & $182.00 \pm 24.60$ & $126.25 \pm 20.61 * *$ & $-55.75 \pm 6.29 * * *$ & $0.71 \pm 0.02 * * *$ & $5.75 \pm 0.53$ \\
\hline III & $182.50 \pm 16.05$ & $141.00 \pm 18.70^{*}$ & $-41.50 \pm 18.28^{* * * *}$ & $0.87 \pm 0.03^{* * * * \dagger}$ & $6.21 \pm 0.24$ \\
\hline IV & $179.00 \pm 23.12$ & $149.75 \pm 25.53$ & $-29.25 \pm 5.37 * * * \dagger$ & $0.97 \pm 0.02 * * * \dagger \dagger$ & $6.58 \pm 0.66$ \\
\hline V
\end{tabular}

Values are expressed as mean \pm SEM $(\mathrm{n}=5)$, One way ANOVA followed by Dunnett's t-test (SPSS 21$), * P<0.05, * * P<0.01, * * * P$ $<0.001$ with respect to Normal gr; ${ }^{\dagger} P<0.05,{ }^{\dagger} P<<0.01$ with respect to CP gr; Group I-Normal control , Group II-CP (200 mg/kg), Group III-CP+AEPF (200 mg/kg) and Group IV-CP+AEPF (400 mg/kg); (-)=weight loss.

Table 3: Effect of aqueous extract of Phyllanthus fraternus leaves on serum creatinine, urea and albumin in cyclophosphamide induced nephrotoxic rats after 10 days treatment.

\begin{tabular}{|llll|}
\hline Groups & S. Creatinine $(\mathrm{mg} / \mathrm{dl})$ & S. Urea $(\mathrm{mg} / \mathrm{dl})$ & S. Albumin $(\mathrm{g} / \mathrm{dl})$ \\
\hline Baseline & $0.77 \pm 0.06$ & $17.50 \pm 0.9$ & $3.88 \pm 0.12$ \\
\hline I & $0.76 \pm 0.07$ & $18.40 \pm 0.75$ & $3.85 \pm 0.15$ \\
\hline II & $2.55 \pm 0.10^{* *}$ & $55.50 \pm 0.96^{* *}$ & $2.16 \pm 0.11^{* *}$ \\
\hline III & $2.00 \pm 0.08^{* * \dagger}$ & $40.00 \pm 2.16^{* * \dagger \dagger}$ & $2.95 \pm 0.11^{* * \dagger}$ \\
\hline IV & $1.55 \pm 0.10^{* * \dagger \dagger}$ & $32.00 \pm 1.83^{* * \dagger+t}$ & $3.24 \pm 0.10^{* \dagger \dagger}$ \\
\hline
\end{tabular}

Values are expressed as mean \pm SEM (n=5) One way ANOVA (SPSS 21), $* P<0.05, * * P<0.001$ with respect to Normal gr; ${ }^{\dagger} P<0.01,{ }^{\dagger \dagger} P$ $<0.001$ with respect to CP gr; ${ }^{\sharp} P<0.05, \$ P<0.01$ with respect to gr III; Baseline Group-before start of experiment, Group I-Normal control, Group II-CP (200 mg/kg), Group III-CP+AEPF (200 mg/kg) and Group IV-CP+AEPF (400 mg/kg).

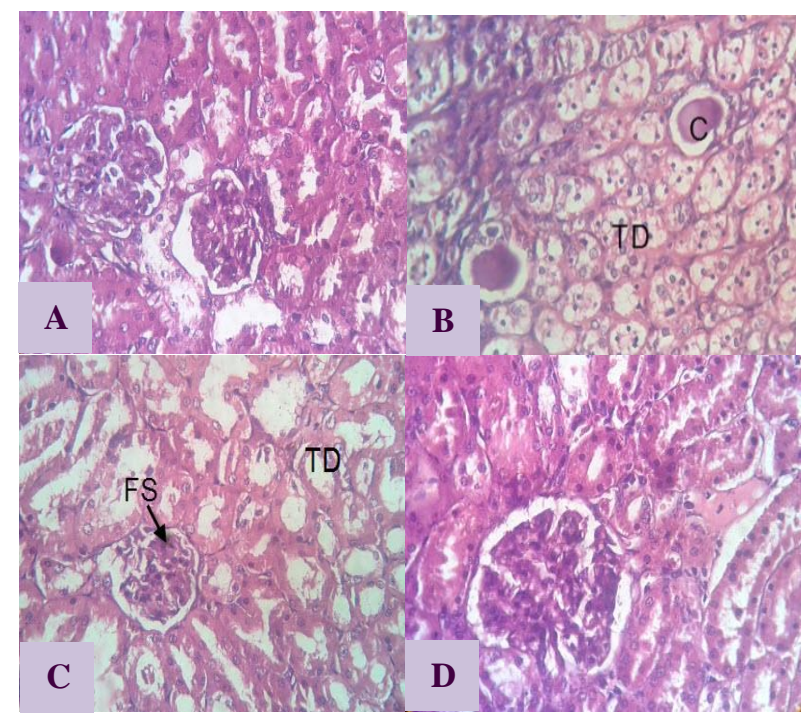

Figure 1: Photomicrograph of kidney tissues in (A) Normal, (B) CP (200 mg/kg) treated, (C) CP+AEPF $(200 \mathrm{mg} / \mathrm{kg}$ ) treated and (D) CP+AEPF (400 mg/ kg) treated rats. $\mathrm{C}$-cast, $\mathrm{TD}$-tubular degeneration and dilatation, FS-focal sclerosis of glomeruli. Stain: $H$ and E. 40x.

Tissue sections from the kidneys of rats treated with $\mathrm{CP}$ showed decreased Bowman's capsule space with focal sclerosis, loss of tubular brush border, epithelial cell necrosis and shedding, luminal cast and congestion of glomerular capillaries. However, no interstitial inflammatory cell infiltration was seen. Tissue sections from the groups co-treated with $\mathrm{CP}$ and AEPF revealed reduced tubular damages and decreased focal sclerosis when compared with that of $\mathrm{CP}$ only treated groups (Figure 1). As histological scoring system gives lucid inter-group comparision, the average group scores showed significant differences. Maximum scores were noted in cyclophosphamide treated group. Extract treatment showed dose dependant improvement in histological scores (Table 4).

Table 4: Histological scoring for severity of renal tissue damage.

\begin{tabular}{|ll|}
\hline Groups & Histological scoring \\
\hline I & $0.20 \pm 0.20$ \\
\hline II & $4.80 \pm 0.20 *$ \\
\hline III & $3.60 \pm 0.25^{*}$ \\
\hline IV & $2.40 \pm 0.25^{* \dagger \dagger}$ \\
\hline
\end{tabular}

Values are expressed as mean \pm SEM $(n=5)$ One way ANOVA (SPSS 21), ${ }^{\mathrm{P}}<0.001$ with respect to Normal gr; $\uparrow \mathrm{P}<0.05, \dagger \dagger \mathrm{P}$ $<0.001$ with respect to $\mathrm{CP}$ gr; $₫ \mathrm{P}<0.05$ with respect to gr IV; Group I - Normal control , Group II - CP (200 mg/kg), Group $\mathrm{III}-\mathrm{CP}+\mathrm{AEPF}(200 \mathrm{mg} / \mathrm{kg}) \&$ Group IV - CP + AEPF (400 $\mathrm{mg} / \mathrm{kg}$ ).

\section{DISCUSSION}

Cyclophosphamide causes cell damage and apoptosis resulting in body weight loss and shrinkage of kidneys. ${ }^{32}$ Aqueous extract of Phyllanthus fraternus treatment may have prevented these damaging effects and retards the loss of body and kidney weights. 
Serum creatinine concentration is a useful marker for injuries and dysfunction of kidneys. ${ }^{33}$ In our study, CP administration led to a marked increase in serum level of creatinine. Co-treatment of AEPF with CP brought down elevated levels of creatinine remarkably. The elevation in serum creatinine is attributed to increased muscle catabolism of creatine to creatinine and decreased elimination of creatinine due to destruction of nephrons. ${ }^{34}$ The decrease of creatinine level in our study showed that AEPF treatment might have prevented both the processes. Urea, a by-product of amino acid catabolism, also rises in the blood in a similar way i.e. increased accumulation and decreased elimination in urine. ${ }^{35}$ The fall in serum urea level in AEPF treatment group might be attributed to reduced generation and/or increase excretion.

Serum albumin levels are maintained if the glomerular integrity is intact. In acute toxic nephropathy model using short study period, renal albuminuria may be a major cause of hypoalbuminemia owing to its long plasma halflife. Reduced serum albumin level signifies damage to glomerular barrier leading to renal albumin loss. ${ }^{36}$ The prevention of decline in the albumin level in AEPF treated rats might signify its protective role in glomerular injury. Histopathological study and comparision of renal sections is considered the gold standard parameter in evaluating nephrotoxic studies and to assess the preventive interventions taken up. ${ }^{37}$ Nephrotoxic features seen in CP treated rats are consistent with other similar studies using CP as inducing agent. ${ }^{38,39}$ The extract treatment prevented the pathological changes in the renal architecture. However, absence of inflammatory cell infiltrates suggests the immunosuppressive effect of CP. This adds to our understanding that the oxidative stress from the toxic metabolites of $\mathrm{CP}$ is the main cause of renal structure damage. Free radicals and reactive metabolites of CP like acrolein generated in the body of rat depleted the antioxidant reserve and mediated the destruction of renal glomeruli and tubules. Enriching antioxidant levels in renal tissue might have prevented the progression of tissue destruction and restore normal renal architecture. ${ }^{40}$ Phytochemical analysis of AEPF revealed the presence of flavonoids, alkaloids, steroids, tannins and terpenoids which are also reported in previous screening studies. ${ }^{15,16}$ The nephroprotective activity of $P$. fraternus is probably due to the presence of flavanoids which is a good antioxidant. ${ }^{41}$ The biochemical and histopathology provided substantial evidences of protection offered by the plant. Therefore, our study suggests the potential role of AEPF as nephroprotective agent and may serve as a promising herbal medicine for use in kidney ailments.

\section{CONCLUSION}

The study shows that aqueous extract of Phyllanthus fraternus provides protection against cyclophosphamide induced nephrotoxicity. The protective potential may be due to free radical scavenging and antioxidant capacity of the plant extract by virtue of its flavonoid constituents.
Further studies will be promising to elucidate mechanism of the nephroprotection.

\section{ACKNOWLEDGEMENTS}

Authors would like to respectfully acknowledge the contribution of Dr. PK Singh, Professor, Department of Life Sciences, Manipur University in the identification of the study plant. Authors thank their staffs and technicians from Department of Pharmacology and Pathology who assisted the research. We thank Prof. Kaushik Debnath, Head of Department of Pathology for his co-operation in carrying out the histopathological study. Authors would also like to show our gratitude to Prof. S. Rita, Head of Department of Pharmacology for sharing her knowledge and wisdom during the course of this research.

\section{Funding: Department of Biotechnology, Tezpur, India Conflict of interest: None declared \\ Ethical approval: The study was approved by the Institutional Animal Ethics Committee}

\section{REFERENCES}

1. Porter GA, Bennett WM. Nephrotoxic acute renal failure due to common drugs. Am J Physiol. 1981;241(7): F1-8.

2. Lakshmi SM, Reddy TUK, KSS. A review on medicinal plants for nephroprotective activity. Asian J Pharm Clin Res. 2012;5(4):8-14.

3. Gershwin ME, Goetzl JE, Steinberg DA. Cyclophosphamide: Use in practice. Ann Intern Med. 1974;80:531-40.

4. Milsted AVR, Jarman M. Metabolism of high doses of cyclophosphamide. Cancer Chemother Pharmacol. 1982;8:311-3.

5. Nolin TD, Himmelfarb J. Mechanisms of druginduced nephrotoxicity. In Adverse drug reactions: Berlin Heidelberg Springer. 2010:111-30.

6. Maheshwari JK. Flora of Delhi-council of scientific and industrial research. 3rd ed. New Delhi: NK Gossain and Co. Private Ltd;1963.

7. Ravindra S. Medicinal plants of India an encyclopedia. 2nd ed. Delhi: Daya Publishing House; 2003.

8. Nasri H, Nematbakhsh M, Rafieian-Kopaei M. Ethanolic extract of garlic for attenuation of gentamicin-induced nephrotoxicity in wistar rats. Iran J Kidney Dis. 2013;7(5):376-86.

9. Nasri H, Nematbakhsh M, Ghobadi S, Ansari R, Shahinfard N, Rafieian-kopaei M. Preventive and curative effects of ginger extract against histopathologic changes of gentamicin-induced tubular toxicity in rats. Int $\mathbf{J}$ Prev Med. 2013;4(3):316-21.

10. Molina-Jijón E, Tapia E, Zazueta C, El Hafidi M, Zatarain-Barrón ZL, Hernández-Pando R, et al. Curcumin prevents $\mathrm{Cr}$ (VI)-induced renal oxidant damage by a mitochondrial pathway. Free Radic Biol Med. 2011;51(8):1543-57. 
11. Sonkar N, Ganeshpurkar A, Yadav P, Dubey S, Bansal D, Dubey N. An experimental evaluation of nephroprotective potential of Butea monosperma extract in albino rats. Indian $\mathbf{J}$ Pharmacol. 2014;46(1):109-12.

12. Khanam SA, Mohan NP, Devi KS, Sultana RO. Protective role of Tinospora cordifolia against cisplatin-induced nephrotoxicity. Int J Pharm Pharm. Sci 2011;3(4):268-70.

13. Oudhia P. Phyllanthus fraternus Webster GL. In: Schmelzer GH, Fakim AG, editors. Prota 11(1): medicinal plants/plantes médicinales 1 . Wageningen, Netherlands: PROTA. 2008:1-6. Available from URL:http://www.prota4u.org/protav8.asp?p=Phyllant hus+fraternus. Accessed on 21 August, 2014.

14. Sharma SK, Sheela MA. Pharmacognostic evaluation of leaves of certain Phyllanthus species used as a botanical source of Bhumyamalaki in Ayurveda. Ayu. 2011;32(2):250-3.

15. Mehta K, Patel BN, Jain BK. Phytochemical analysis of leaf extract of Phyllanthus fraternus. Res J Recent Sci. 2013:2;12-5.

16. Christian M. Steroids - chemical constituents of Phyllanthus fraternus Webster through TLC and HPTLC. Int Res J Chem. 2013;1(1):29-48.

17. Upadhyay R, Chaurasia JK, Tiwari KN, Singh K. Antioxidant property of aerial parts and root of Phyllanthus fraternus Webster, an important medicinal plant. Scientific World J. 2014;1(1):1-8.

18. Kumari KK, Setty OH. Protective effect of Phyllanthus fraternus against mitochondrial dysfunction induced by co-administration of cisplatin and cyclophosphamide. $\mathrm{J}$ Bioenerg Biomembr. 2012;44(1):179-88.

19. Verma SCL, Agarwal SL. Studies on Leptadenia reticulate: Part II, preliminary chemical investigations. Indian J Med Res. 1962;50(1):439-45.

20. Kokate CK, Purohit AP, Gokhale SB. Pharmacognosy. 43rd ed. Pune: Nirali Prakashan; 2009.

21. Trease GE, Evans WC. Pharmacognosy. 11th ed. London: Bailliere Tindall; 1989.

22. OECD. OECD guideline for testing of chemicals 423: Acute oral toxicity-acute toxic class. Available from

URL:https://ntp.niehs.nih.gov/iccvam/suppdocs/fedd ocs/oecd/oecd_gl423.pdf. Accessed 14 July, 2013.

23. Kirkwood BR, Sterne JAC. Essential medical statistics. 2nd ed. Massachusetts: Blackwell Science Ltd; 2003.

24. Medhi B, Prakash A. Practical manual of experimental and clinical pharmacology. New Delhi: Jaypee Brothers Medical Publishers (p) Ltd; 2010.

25. Jaffe MZ. About the precipitation caused by pikrinic acid in normal urine and about a new reaction of creatinine. Physiol Chem. 1886;10:391-400.

26. Berthelot MP. Berthelot's reaction mechanism. Report Chim Appl. 1859;2884.
27. Kaplan A, Szabo L. Clinical Chemistry in interpretation of techniques. 2nd ed. Philadelphia: Lea and Febigel;1983.

28. Bailey SA, Zidell RH, Perry RW. Relationships between organ weight and body/brain weight in the rat: what is the best analytical endpoint? Toxicol pathol. 2004;32(4):448-66.

29. Durry RAB, Wallington EA. Carleton's histological technique. 4th ed. New York: Oxford University Press; 1967.

30. Klopfleisch R. Multiparametric and semiquantitative scoring systems for the evaluation of mouse model histopathology-a systematic review. BMC Vet Res. 2013;9(1):123-37.

31. Sahni SK. Indian National Science Academy. Guidelines for care and use of animals in scientific research. New Delhi: Bengal Offset Works; 2000.

32. Blankenberg FG, Tait JF, Strauss HW. Apoptotic cell death: Its implications for imaging in the next millennium. Eur J Nucl Med. 2000;27(3):359-67.

33. Biomedical FA. NIH definition of biomarker. Clin Pharmacol Ther. 2001;69:89-95.

34. Leelahavanichkul A, Souza AC, Street JM, Hsu V, Tsuji T, Doi K, et al. Comparison of serum creatinine and serum cystatin $\mathrm{C}$ as biomarkers to detect sepsisinduced acute kidney injury and to predict mortality in CD-1 mice. Am J Physiol Renal Physiol. 2014;307(8):F939-48.

35. Weiner ID, Mitch WE, Sands JM. Urea and ammonia metabolism and the control of renal nitrogen excretion. Clin J Am Soc Nephrol. 2015;10(8):144458.

36. Haraldsson B, Nystrom J, Deen WM. Properties of the glomerular barrier and mechanisms of proteinuria. Physiol Rev. 2008;88(2):451-87.

37. Blank M, De Felice A, Goodsaid F, Harlow P, Hausner E, Jacobson-Kram D et al. Review of qualification data for biomarkers of nephrotoxicity submitted by the predictive safety testing consortium, 2009.

38. Sakr SA, Abdel-Samie HA. Effect of Ginko biloba extract on cyclophosphamide-induced nephrotoxicity and oxidative stress in albino rats. Can J Pure Appl Sci. 2016;10(2):3835-45.

39. Shahana ARAA, Karale S, Kamath JV. Nephroprotective effect of Mentha longifolia against cyclophosphamide induced nephrotoxicity in rats. Int Res J Pharm 2016;7(6):77-82.

40. Singh M, Kumar N, Shuaib M, Garg VK, Sharma A. A review on renal protective agents for cyclophosphamide induced nephrotoxicity. World J Pharm Pharmaceut Sci. 2014;3:737-47.

41. Talele BD, Mahajan RT, Chopda MZ, Nemade NV. Nephroprotective plants: a review. Int J Pharm Pharm Sci. 2012;4(1):8-16.

Cite this article as: Moirangthem RS, Gunindro N, Takhellambam DS, Khuraijam SD, Meena N, Rita S. Protective effect of Phyllanthus fraternus against cyclophosphamide-induced nephrotoxicity in rats. Int J Basic Clin Pharmacol 2017;6:984-9. 